\title{
Reservations are Restrictions of Present India
}

\author{
Naveed Naseem \\ School of Legal Studies, Central University of Kashmir, India
}

\begin{abstract}
This paper looks around the reservation policy in India and its correlation with the constitutional framework of the country, to find its effectiveness and ground zero implications. The study indicated political representation throughout the country is polarizing the common masses of the country for their vote bank politics and personal interests instead of fulfilling the burning spirit behind the reservation provisions in Indian constitution. Instead of supporting minorities and other backward class, it has adversely affected the majority.
\end{abstract}

Keywords: backward classes, masses, personal interests, reservation, vote bank

\section{Introduction}

Indian society has been full of inequalities. It was a caste ridden society, stratified hierarchical society and many communities of society had been denied basic human rights. Their entire living conditions and status was dictated by upper strata of society and thus depriving them even of the dignity of life. These barbaric and inhuman conditions attracted the attention of "we the people" impelling the framers of Indian constitution to think. The framers of Indian constitution adopted many provisions for reservation to weaker and underprivileged sections of Indian society. But unfortunately these constitutional provisions had been misused, abused and overused by politicians for their vested interests. If we go back to 1858 we could find British people knew how to divide and rule India, and with this policy they kept dividing India on name of Religion, caste and sub caste. But the tragedy of India is that, when British people left they handed over the India to such people who changed nothing what was started by British, Indian rulers and politicians kept on doing same things, ruling India with same rules and regulations of British. Before independence as well as after independence sad story is that we never got any opposition party who wanted to change this. And introduce reservation in everything in India on the basis of collective salary of family. All political parties know that divide and rule policy based on religion and caste will make them rich, will always help them to hide their evil deeds. Today now in India this has become permanent method to give reservations to get more votes and no one has authority to stop this as rulers justify their actions, taking refuge in constitution.

\section{Protection Under Constitution of India}

The guiding principle of Constitution of India is Equality before law and Equal protection of law to all its citizens. Unlike natural laws, human made laws are always with exceptions and the constitution of India is not new to this.

Under Article 15 (3) of the Constitution, any special provision may be made for women and children belonging to all social groups transcending caste, religion etc., for their advancement and welfare in all fields. Under Article 15 (4), special provisions may be made for the advancement of any socially and educationally backward class and for the Scheduled Castes and the Scheduled Tribes. Article 16 (4) permits the state to make any provision for the reservation of appointments or posts in favour of any backward class, which, in the opinion of the state, is not adequately represented in the services under it. Similarly directions are been given to state under Article 46 that directs the state to promote with special care the educational and economic interests of the "weaker sections of the people", particularly of the Scheduled Castes and the Scheduled Tribes and also directs the state "to protect them from social injustice and all forms of exploitation". Although prima facie, these appear to be the exceptions to the citizen ${ }^{\text {ec }}$ right to equality before law or to the equal protection of the laws guaranteed by Article 14. Analysis from ground zero reveals that these provisions only do a lip service to underprivileged as there is little evidence that it has made a difference to the poor over the 65 years of practicing it, but the system cannot be scrapped or changed easily as the social disadvantages remain a contentious issue.

The constitutional framers drafted reservation provision with very good objective of uplifting the socially backward society to give them equality of opportunities at par with privileged or general ones. But with the passage time its meaning and the way it has been taken by the people has left most of us to believe that it has stopped delivering for what it was made.

\section{Mandal Commission Report}

The Mandal commission was established in India 1979 by the Janata Party government under Prime Minister Morarji Desai with a mandate to identify the socially or educationally backward. It was headed by Indian parliamentarian B. Prashad Mandal to consider the question of seat reservations and quotas for people to redress caste discrimination, and use social, economic and educational indicators to determine backwardness. This commission was setup under Article 340 for the purpose of Article 15 and 16. It recommended change to these quotas, increasing them by $27 \%$ to $49.5 \%$. Regarding reservations of Scheduled castes and Scheduled tribes are that India constitutes of $22.5 \%$ SC and ST population and accordingly $22.5 \%$ reservations has been made for them in all services and public sector under central government and reservation in states should be according to their population.

For other backward classes recommendations for reservation is that they are $52 \%$ of total population of India. 


\section{International Journal of Science and Research (IJSR) \\ ISSN (Online): 2319-7064 \\ Index Copernicus Value (2013): 6.14 | Impact Factor (2015): 6.391}

Accordingly $52 \%$ of all the posts under central government should be reserved for them but in view of Supreme Court judgments it has been held that total quantum of reservation should be below $50 \%$. In view of this proposed reservations for OBC, SC and ST together should be less than 50\%. Therefore commission has assigned $27 \%$ reservation for them. The recommendation were that $27 \%$ of jobs in government services and public undertaking be reserved for OBC thus bringing total in the reserved category to $49.5 \%$ as $22.5 \%$ was already reserved for SC and ST. the announcement was greeted with widespread anger as VP Singh did not even consult close associates.

The worst effect of mandal commission was that it was socially divisive; it pitted caste against caste in the name of social justice. It was followed by strong and violent reaction of student's community in north India. The protest ended when Supreme Court of India granted stay on implementation of Mandal commission report on 1 Oct 1990. Student of Delhi University Rajiv Goswami committed immolation in protest.

\section{Judicial Treatment}

In the historic case of Indra Sawhney vs. Union of India,1992 popularly known as the mandal case, supreme court examined the scope and extent of reservation under Article 15(4) and 16(4) respectively in detail and clarified various aspects on which there were difference of opinion in various earlier judgments. The majority opinion of Supreme Court may be summarized briefly as follows:

Article 16(1) permits classification for ensuring attainment of equality of opportunity guaranteed under Article 16(1) itself.

Article 16(4) is not an exception to Article 16(1) but only an instance of classification implicit and permitted by Article 16(1).

Backwardness contemplated in article 16(4) do not necessarily refer to social and educational backwardness.

Poverty cannot be the sole criterion for determining the backward classes.

\section{Exclusion of creamy layer.}

Reservation shall not ordinarily exceed 50\% barring extraordinary situations which may warrant relaxation of this rule.

No reservation in the matters of promotion.

After Indra Sawhney where the court held that reservation under Article 16(4) must only be confined to appointment and not promotion and that $50 \%$ ceiling limit should be applied, so as not to choke the general category, the government for their vote bank interests amended the constitution inserted Article $16(4-\mathrm{A})$ by constitutional $77^{\text {th }}$ amendment Act, 1995 to dilute the effect of Indra Sawhney Judgment, empowering state for making any provision for reservation in matters of promotion, with consequential seniority, to any class or classes of posts in service under the state in favour of SC/STs which in the opinion, are not adequate by represented in the services under state.
Again by constitutional $81^{\text {st }}$ amendment Act, 2000 Article 16(4-B) was inserted to permit government to treat the backlog of reserved vacancies as separate and distinct, to which the limit of $50 \%$ ceiling in reservation does not apply. Simply trying to legitimize their ill motivates for political gains having least regard to over all scenario of nations development.

H.M Seervai criticized the Judgment of Indra Sawhney primarily on the ground that court should not have relied on the recommendations of the Mandal Commission which formed the basis of the office memoranda.

\section{Wake Up Call for India}

In 1950, quota for backward classes was made and from time to time, many new quotas and reservations have been added to this. Contrary to world trend, with development the reservation quota in India is on rise leaving a psychological fear in the minds of general ones. As country is moving towards "Digital India", "Make in India" and "Nuclear India" our reservation quota is about to make fifty(49.5\%). Reservation is working in the opposite direction to its main objective as is demarcating the society further and the credit goes to our so called political representation. Political parties always use reservations as a political weapon for their political gains leaving scars on plural ethos and overall development of country. It is being used to uplift one section of the society at the cost of another, which is not fair. On one hand country is fighting casteism and on the other side Political representation is promoting caste-based reservations for their political gains. At international level India talks of unity and universal brotherhood but within its states it is strengthening casteism by promoting reservations. Today we stand divided widely into Hindu, Muslim, ST, SC and OBCs with newer reservations coming up for other sections of society like Christens, Kashmiri Pandits, Jhats etc. Today when students apply for admissions in colleges and universities, they are asked questions „Are you SC, ST, OBC or General Category? How does it matter which category he belongs, what matters is his merit.

Article 15(4) empowers the government to make special provisions for advancement of backward classes. But what surprises us is that constitution nowhere defines term "backward classes". Here, our so call political representation plays a role and take undue advantage for their vote bank politics by notifying certain communities as backward class not on the basis of merit but on the basis of vote bank. On one hand preamble of constitution states "we the people of India", but on the other hand reservation system is trying to modify it "we the people of SC, we the people of ST and we the people of OBC". Reservations are means to prosper the vote banks of politicians.

Moreover, a capable candidate does not need any certificate of being from a lower caste to prove their worth. It is his merit, education and ability to compete that can bring change in life. Taking a seat just by showing your under privileged certificate won 't give you anything, but just the degree or a job. Also the reservation system in India is creating a workforce which is not capable enough to compete at the global level. India needs people for growth

\section{Volume 5 Issue 4, April 2016}




\section{International Journal of Science and Research (IJSR) \\ ISSN (Online): 2319-7064}

Index Copernicus Value (2013): 6.14 | Impact Factor (2015): 6.391

and development but reservation is adding undeserving candidates as well.

\section{Conclusion}

Thus, while on one hand, the constitution itself guarantees the right to equality of status and opportunity but on other hand, it provides some special provisions as of fundamental right under part third of constitution for advancement of certain backward classes including SCs and STs. Thus as regard to General ones, those provisions may appear to be a sanction for discrimination. Thus the concept of equality under Indian constitution seems to be greatly diluted and the whole efforts of providing equaliy throughout the constitution are under the moist of discrimination in one way or other.

So reservation system should be demolished and if the government really wants to uplift the underprivileged sections of the society then a well-balanced policies should be formulated. First of all such sections of the society should be clearly identified that need development and financial aids. Then to uplift them free education, or incentives and financial assistance should be provided. Once done let them face the competition, true competition. Make them capable, show them the right path and infuse a fighting spirit in them as no one is against healthy competition. There was a quota system in US as well, but it was abolished long ago. But it does not mean that they are not working for the underprivileged in their society. For admission and appointment purposes, now they have point systems in which people from backward regions are given some extra points but, not a certain number of seats. So, though the government is helping the needy, but it is not at all discriminating or snatching away the rights of eligible candidates. Also from time to time such reforms or laws must be evaluated by experts and their impact on the development of under privileged and overall society must be assessed. Politicians should stop using reservation system as a gimmick to have a permanent vote bank. Education should not be a part of politics. Instead nurture the sapling right from childhood for their bright future and then there won't be any need of so called reservation system in India.

The policy of reservation was designed as an adhoc policy for ten years. But it is continuing and getting extension after the end of every ten years. It is creating a sort of frustrations among the general ones as they are deprived of opportunities either to get job or to take admission in any educational institution due to the reservation policy. The reservation policy has actually created a new class of vested interest in the society. They are earned permanently the benefit of reservation policy, thereby creating the psychology of dependency among them. It has given rise to politics of casteism in our political system which impediments the national integration. They are competing among themselves for enhancing the percentage of reservation. When the reservation quota increased to $70 \%$, no doubt the general ones would be minorities in future demanding reservations for them and the cycle will continue. Contrary to popular opinion, a social safety net is the most effective way to raise the standards of disadvantaged groups- this has been proven using data from various countries.

\section{References}

[1] J.N Panday, Constitutional Law of India,(Allahabad: Central Law Agency) 2009.

[2] H.M. Seervai- Constitutional Law of India, A critical commentary, vol.1 2005.

[3] V A Pai Panadikar, The politics of Backwardness: Reservation policy in India, New Delhi, Konark, 1997.

[4] Indra Sawhney v. Union of India and ors. 1992 supp (3) SCC 212. 